航走出会い波浪の特性

\title{
徳長航* 桑島進** \\ Characteristics of the Measured Waves by a Ship under Way
}

\author{
Wataru TOKUNAGA and Susumu KUWASHIMA
}

\begin{abstract}
The shipborne-type wave height meter-using microwave Doppler radar is capable to measure the ocean waves while she is steaming. Instruments of this type are already installed on more than 100 ships. The encountering wave period measured by the instrument onboard depends on the ship's speed and the course. But it has seemed that ship's speed and course do not affect the wave height. However, there are some recent reports that the wave heights measured at the almost same time in various ship's course are different from each other. So, we investigated the characteristics of waves measured by a ship under way using the numerical simulation technique.

In the result, it became clear that the frequency distribution of the wave heights is affected according to the encountering period of component waves. The significant wave height is defined as the mean of the highest one-third of the waves. So, It is not strange that the significant wave height of following waves is smaller than that of the head waves. On the other hand, the value of estimated significant wave height, which is derived from the wave spectrum, is not generally affected by ship's speed and course.
\end{abstract}

\section{1.はじめに}

大洋における波浪観測は依然として乗組員による 目視観測が主体となっている。しかし目視観測は人 間の主観に左右され易いためその精度については簃 問が付きまとってきた。さらに近年、乗組員の人数 削減や外国人船員化の影響を受けて気象庁への観測 報告数は年々減少の一途を辿っている(1)。このよう なマイナス面を解決する一手段として客観的な值を 自動計測する舶用波高計の開発が叫ばれてきた。こ の声に応えるべく開発されたマイクロ波式波高計 ${ }^{(2)}$ は船舶が航走しながら波浪を計測できる利便性を 持っているところから本邦内外の大学や官庁船など を中心にすでに 100 隻以上の装備実績があり、装備船 の数は今後とも増加するものと思われる。

ただし、当該波高計によって得られる波浪の周期 は船舶が航走しながら計測することから、船速拉よ び波の進行方向に対する船首方向によって異なる “出会い周期”である。一方、波高は航走する船舶
に対する出会い波高とはいえ、海面の垂直変動だけ を計測していることから船速や船首方向によって異 なることは無い“絶対波高”と思ってきた。ところ が、最近に至り当該波高計による波高值が、波向き に対寸る船首方向によって異なる傾向があるとの報 告が寄せられた ${ }^{(3,4)}$ 。不規則海面に対する波高は一般 に有義波高を指しており、先の報告は有義波高の方 向別相違を指摘したものである。すなわち、この報 告は波高を含む不規則波形の統計的性質が、航走出 会い波浪の場合は方向別に異なって算出される可能 性を示唆している。そこで、波向きによる計測波高 の差を明らかにすべく出会い波浪の統計的性質につ いて改めて数值シミュレーションを用いて検討した 結果、算出方法による統計值の差とその特性が明ら かとなったのでここに報告する。

\section{2. シミュレーション波浪の発生方法}

外洋波のスペクトルの標準形として使用される Pierson-Moskowitz (以下、P-M) スペクトル(5)を

* 学生会員 東京商船大学大学院（干135-8533 江東区越中島2-1-6）

**名誉会員 東京商船大学（于135-8533 江東区越中島2-1-6) 
用いて、出会い波の方向、船速などの違いによる波 形の得られ方のシミュレーションを行った。この得 られたシミュレーション不規則波形からゼロアップ クロス法やスペクトル解析等の方法により、有義波 高や出会い周期などを計算し、それらの信頼性や精 度について比較解析を行った。

\section{$2.1 \mathrm{P}-\mathrm{M}$ スペクトル}

外洋の風成波発生域内で十分に発達した風波スぺ クトルとかなりよい一致を示している $\mathrm{P}-\mathrm{M}$ スペク トルを用いてシミュレーションを行った。 $\mathrm{P}-\mathrm{M}$ スペ クトルとは、十分に発達し吹送距離には無関係に なったと考えられる波浪スペクトルを風速の関数と して一般化したものであり、P-Mスペクトル $\phi(f)$ は、

$$
\begin{aligned}
\phi(f) & =k_{1} f^{-5} \exp \left(-k_{2} f^{-4}\right) \\
k_{1} & =8.1 \times 10^{-3} g^{2} /(2 \pi)^{4} \\
k_{2} & =0.74\left[\frac{g}{2 \pi U}\right]^{4}
\end{aligned}
$$

のように表される。ここで $g$ は地球重力加速度 $(g=$ $\left.9.8 \mathrm{~m} / \mathrm{s}^{2}\right)$ である。本来の $\mathrm{P}-\mathrm{M}$ スペクトルの風速は $U_{19.5}$ であり、これは海面上 $19.5 \mathrm{~m}$ における風速であ る。今回のシミュレーションの場合は単に外洋での 波形を得るために用いたので、 $U_{19.5}=10 \mathrm{~m} / \mathrm{s}$ として シミュレーションを行った。

\section{2 波形の作成}

先のP-Mスペクトルから時系列波形 $\eta$ を得るに は、風速 $U$ に対応する $\mathrm{P}-\mathrm{M}$ スペクトルのピーク周波 数から高周波側、低周波側共にパワーがピーク值の 1000分の1を示すまでの周波数を $0.001 \mathrm{~Hz}$ ごとに分 割し、それぞれの分割領域周波数に対する成分波を

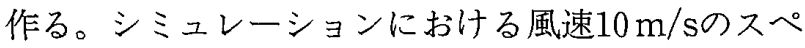
クトルに対するピーク周波数は $0.137 \mathrm{~Hz}$ であり、最 低周波数は $0.080 \mathrm{~Hz}$ 、最高周波数は $0.699 \mathrm{~Hz}$ であっ た。周波数間隔は $0.001 \mathrm{~Hz}$ であるから合計 620 個の 成分波を作ったことになる。一つずつの成分波 $\eta_{n}$ は、

$$
\eta_{n}(t)=a_{n} \sin (2 \pi f t)
$$

のよjにして作る。ここでnは周波数分割領域にお けるn番目の区分を示す。 $\mathrm{P}-\mathrm{M}$ スペクトルの全スぺ クトルエネルギーは、負の周波数部分を折り返した ワンサイドスペクトル（One Side Spectrum）を表 したものであることから、成分波の片振幅 $a_{n}$ は、

$$
a_{n}=\sqrt{2 \phi\left(f_{n}\right) \times \Delta f}
$$

と表される。ここで $\Delta f$ は周波数分割幅（本シミュ レーションに捛いては $0.001 \mathrm{~Hz})$ である。この成分 波をランダムな位相差 $\varepsilon_{n}$ を用いて、

$$
\eta(t)=\sum_{n=1}^{N} a_{n} \sin \left(2 \pi f_{n} t+\varepsilon_{n}\right)
$$

のようにランダムに合成させることにより不規則波 の時系列 $\eta(t)$ を得る。この不規則波時系列は海面の 固定点で計測した時に得られるであろう波形を示し ており、ここでは原波浪と呼ぶことにする。(2.6) 式における重ね合わせ数Nは、0.001 Hz毎に作った 成分波の数620である。シミュレーション波としては 上記の時系列波形 $\eta(t)$ を用い、サンプリングタイム 0.1 秒ごとに抽出点数を $2^{14}$ 個に相当する 16,384 点、 すなわち発生時間を 27.3 分に設定した。この波浪に 航行船の針路に応じた速力を加えることにより、波 形の変化、算出される有義波高、出会い周期の変化 を解析した。

\section{3 船速合成}

先に発生させた原波浪に向波と追い波それぞれに つき、船速を合成させて、向波と追い波での出会い 波形を得る。合成の方法としては、まず原波浪の各 成分波毎の波速 $C_{n}(\mathrm{~m} / \mathrm{s})$ をそれぞれの成分周波数 $f_{n}$ を用いて、

$$
C_{n}=\frac{g}{2 \pi f_{n}}
$$

により求め、船速 $v(\mathrm{~m} / \mathrm{s})$ の船舶が出会うであろう出 会い成分波の周波数 $f_{E n}$ をドップラー効果の次式、

$$
f_{E n}=f_{n}\left|\frac{C_{n}-v \cos \theta}{C_{n}}\right|
$$

により新たに求める。ただし、 $\theta$ は船首方向と波の進 行方向との角度差である。船速と波向きによっては、 出会い成分波の周波数が計算上、負になる場合があ るが、物理的に負の周波数はないため絶対值をとる ものである。この各出会い成分波の周波数を用いて、 上記 (2.4) 式と同様にそれぞれの出会い周波数毎の 成分波 $\eta_{E n}$ を

$$
\eta_{E n}(t)=a_{n} \sin \left(2 \pi f_{E n} t\right)
$$

のようにして作り、それを再び上記 (2.6) 式と同様 に合成した、

$$
\eta_{E}(t)=\sum_{n=1}^{N} a_{n} \sin \left(2 \pi f_{E n} t+\varepsilon_{n}\right)
$$

が求める出会い不規則波浪となる。横波では船速を 合成さても (2.8) 式の $\cos \theta$ の值が 0 になるので船速 の影響は受けず、周波数の変化は起こらないで原波 浪の波形デー夕と同じ形になる。一例として、船速 $12 \mathrm{k}$ t、向波 (上段) と追い波 (下段)の場合のシミュ レーション波形を図 1 に示す。向かい波と追い波で は、波高に差は無さそうであるが、出会い周期は異 
なっているのがわかる。

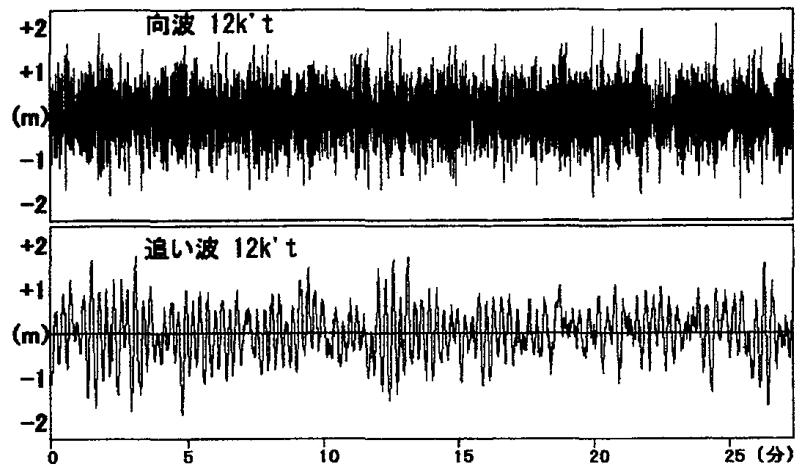

図 1 シミュレーション波形の一例

\section{3. シミュレーション波形の解析}

\section{1 波 高}

今回の解析では航走出会い波浪に対し、波高 $H_{s}$ を 次の3種類の方法で求めた。一つ目は一般に不規則波 形からの波高算出に用いられているゼロアップクロ ス法による $1 / 3$ 最大波高である。この $1 / 3$ 最大波高は Sverdrup Munkにより有義波高と定義されてい る(6)。ゼロアップクロス法は平均水面に対して波形 の値がマイナスからプラスになる交点をゼロアップ クロス点とする。そしてーつのゼロアップクロス点 から次のゼロアップクロス点までを一波として波形 を取り扱う。この一波の時間間隔を周期、その一波 における最大値と最小值の差を波高と定義する方法 である。そしてゼロアップクロス法により得られた 全波高の中で大きい方から三分の一の数の波高を取 ク出して平均した值を $1 / 3$ 最大波高 $H_{1 / 3}$ と定義する ものである。

二つ目は、得られた出会い波形をフーリ工変換し て再びスペクトルで表し、その全スペクトルエネル ギー（波形データの分散 $\eta^{2}$ に等しい值）から換算し て有義波高を推定した波高（以下、スペクトル換算 波高)であり、波の全スペクトルエネルギーを $m_{0}$ と すると、

$$
\begin{aligned}
& H_{s}=4.004 \sqrt{m_{0}} \\
& \text { ただし、 } m_{0}=\int_{0}^{\infty} \phi(f) d f=\eta^{2}
\end{aligned}
$$

の統計的関係式(7) から得られるものである。

三つ目は波高計の表示器に示すための表示用の波 高 (以下、表示波高と記す。)で、先の二つのように 一定時間の観測した後の統計計算によって得られる 波高と異なり、この表示波高は時々刻々と変化する それまでの波高から有義波高を推定計算し、リアル
タイムに表示するものである。表示波高はコンデン サと抵抗の簡単な組み合わせによる電気的平均回路 で構成表示されるが、それを数式化すれば、

$$
\begin{aligned}
& H_{s}=10 \bar{\eta}_{>0} \\
& \text { ただし、 } \bar{\eta}_{>0}=\frac{1}{\tau} \int_{-T}^{0} \eta_{>0}(t) \exp \left(\frac{t}{\tau}\right) d t \\
& \eta_{>0}: \text { 波形データの正の部分 } \\
& \bar{\eta}_{>0}: \eta_{>0} \text { の平均 } \\
& \tau \quad: \text { 時定数 } \\
& T \quad: \text { 平均時間 }
\end{aligned}
$$

により得られる有義波高の推定值である(8)。上式に おける有義波高は時定数を平均時間の半分程度にす ることにより、寒用上十分な精度で推定表示できる ので、今回は $T=6$ 分、 $\tau=3$ 分とした。つまり、現時 点からさかのぼって 6 分間の波形データを考慮し て、現時点の波高が算出されることになる。また、 先の二つの波高と異なり一連のシミュレーション波 形に対し、連続的に波高值が算出される。よって先 の二つの波高值と比較するために、スタート後 6 分 以降の定常状態になった時点から残りの21.3分間の 表示波高值の平均を持ってその一連の波形デー夕を 代表する表示波高とし、同時にその標準偏差(以下、 表示波高の標準偏差)を求めた。

そして、この3 種類の波高と標準偏差を計算させ る動作を一つの船速に対して、向波、追い波、横波 につきそれぞれ異なった出会い波浪の波形で300回 ずつ行った。その計算と同時に、ゼロアップクロス 法による平均波高も求めた。

図 2 に波向き別のゼロアップクロス法による有義 波高である $1 / 3$ 最大波高のグラフを示す。縦軸は波高 $(\mathrm{m}) 、$ 横軸は船速 $\left(\mathrm{k}^{\prime} \mathrm{t}\right)$ である。図によれば、向波に ついては船速が増すにつれて僅かながら直線的な減 少傾向が見られる。追い波では船に追い越されるよ うな成分の波が増えだす $12 \mathrm{k}$ 七あたりから極端に波

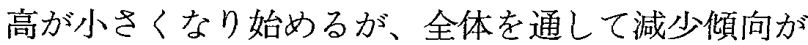
あるのではなく、值としては船速が8k’t付近でやや

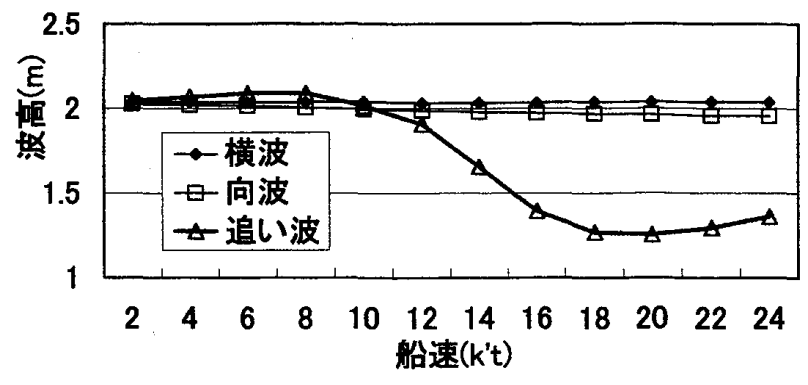

困 2 有義波高（ゼロアップクロス法による $1 / 3$ 最 大波高） 


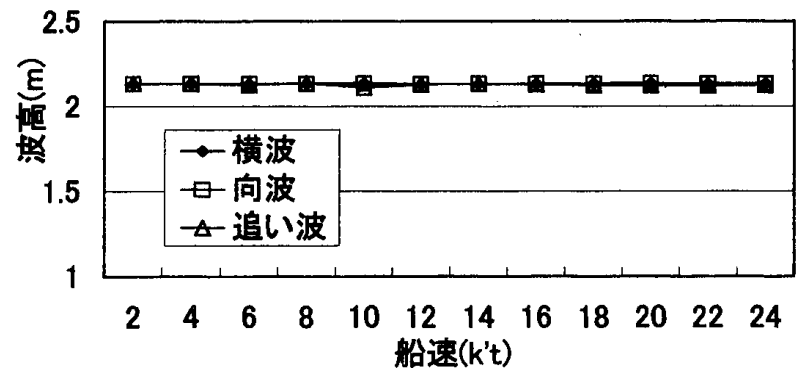

図 3 スペクトルからの換算波高

大きめの值を示すが、その後船速の増加と共に小さ くなり、20k’t付近で最小となっている。

図 3 に（3.1）式で定義した波向き別の出会い波浪 スペクトルからの換算波高のグラフを示す。縦軸は 波高 $(\mathrm{m})$ 、横軸は船速 $\left(k^{\prime} \mathrm{t}\right)$ である。前節のP-Mスぺ クトルの (2.1) 式と全スペクトルエネルギーの (3. 1) 式より換算波高 $H_{s}$ と風速の関係は、

$$
\begin{aligned}
H_{s}= & 0.0213 \times U^{2} \\
& U: \text { 風速 }(\mathrm{m} / \mathrm{s})
\end{aligned}
$$

のように求まる。シミュレーションにおいては風速 を $U=10 \mathrm{~m} / \mathrm{s} に$ 設定したため、(3.5) 式による換算波

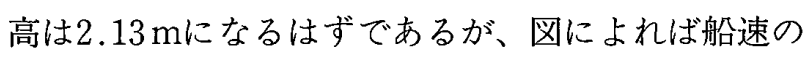
影響、波の向きにかかわらず、非常によく一致して いるのがわかる。また、いずれの波向きにおいても スペクトル換算波高は図 2 に示した有義波高に比べ て全体的にやや大きめに示している。

図 4 に波向き別の表示波高のグラフを示す。困に よれば、追い波において船速が増すにつれ僅かな増 加傾向が見られるが、向波、横波においても船速に よる変化、波向きによる変化はほとんど無い。また、 いずれの波向きにおいても図 2 に示した有義波高や 図 3 に示した換算波高よりも小さな波高を示してい る。

図 5 に表示波高の標準偏差のグラフを示すが、船 速が増すにつれ、追い波の標準偏差は大きく堌加す るが、向波は若干減少する傾向がある。

\section{2 出会い周期}

出会い周期においても有義波高と同様に 3 種類の

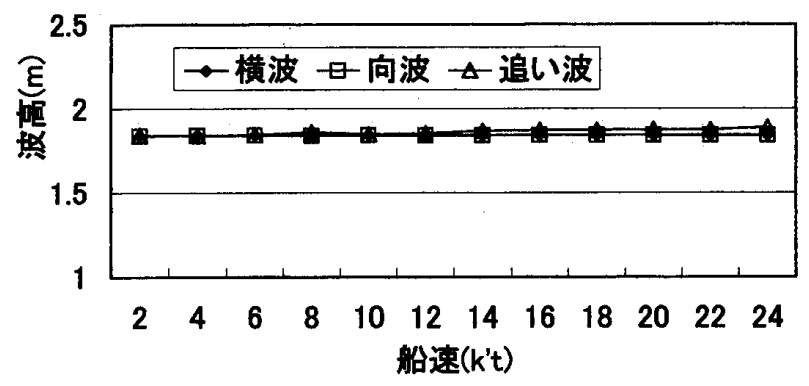

図 4 波高計における表示波高

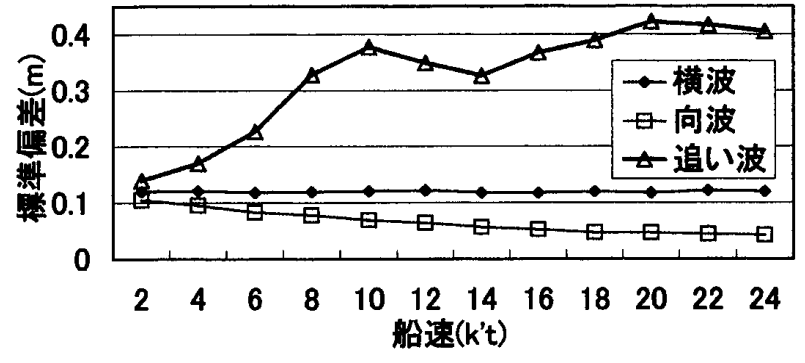

困 5 表示波高の標準偏差

方法で求めた。一つ目は本来の定義(6)に従ったゼロ アップクロス法による周期である。ここでは、ゼロ アップクロス法により得られた、1/3最大波の出会い 周期の平均（以下、有義波出会い周期）とすべての 出会い周期の平均（以下、平均出会い周期）の両方 を求めた。

二つ目は、出会い波浪スペクトルピークからの周 期（以下、スペクトルピーク出会い周期）である。 前節で述べたように出会い波形からフーリエ変換し てスペクトルを平滑化し、最もパワーの強い周波数、 つまりピーク周波数の逆数から得た周期である。

三つ目は、表示出会い周期である。表示波高と同 様に波高計の表示に使用されているもので、先の二 つのように一定時間の観測した後に統計計算によっ て得られる出会い周期と異なり、この表示出会い周 期は時々刻々と変化するそれまでの出会い周期から 現時点での出会い周期が推定計算され、リアルタイ ムに表示するものである。この表示出会い周期 $T_{n}$ は、

$$
\begin{aligned}
T_{n}= & 0.1 T_{0}+0.9 T_{n-1} \\
& T_{0}: \text { 直前の個別波の周期 }
\end{aligned}
$$

で表される。そして、表示波高の場合と同様に、有 義波出会い周期やスペクトルピーク出会い周期と異 なり一連のシミュレーション波形に対し、一つの出 会い周期が算出されるわけでない。よって一連の波 形において得られたすべての表示出会い周期の平均 をもってその一連の波形を代表する表示出会い周期 とし、同時にその標準偏差（以下、表示出会い周期 の標準偏差）を求めた。また、この表示出会い周期 は、式からもわかるように現時点の波形が平均海面 を切った時、つまりその時点での一波の周期が確定 した時にのみ、新しい周期を算出、更新表示するよ うになっている。

波高と同様に、この 3 種類四つの出会い周期と標 準偏差を計算させる動作を一つの船速に対して、向 波、追い波、横波につきそれぞれ波形を変えて300回 ずつ行った。 


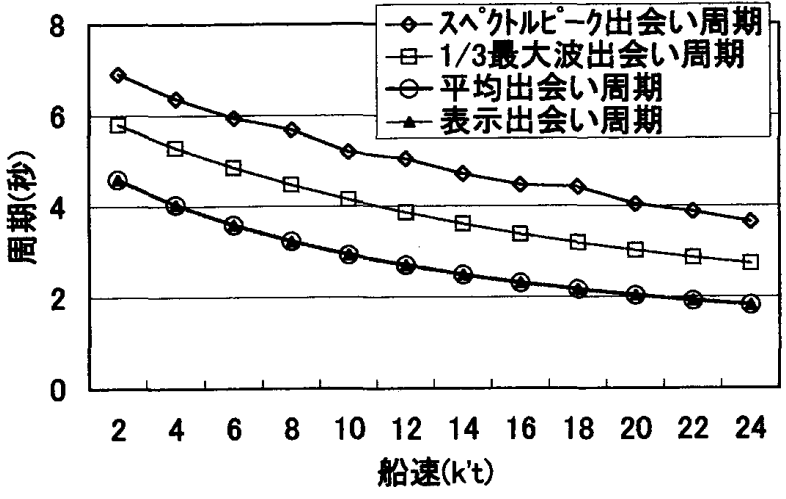

図 6 向波に打ける出会い周期

図 6 に向波における 3 種類四つの出会い周期のグ ラフを示す。縦軸は周期 (秒)、横軸は船速 (k’t)であ る。図によれば、スペクトルピーク出会い周期が最 も長く、次に有義波出会い周期、最も短いのは平均 出会い周期と表示出会い周期で、ほぼ同じ程度で あった。向波であるから、全体として船速が増すに つれ出会い周期は短くなってくる。ここでスペクト ルピーク出会い周期が他の出会い周期に比べ長くな るのは、スペクトルのピーク周期 $T_{p}$ と有義波周期 $T_{1 / 3}$ との関係によるものである。観測データに基づ いて導かれた関係式には、

$$
T_{p} \fallingdotseq 1.09 T_{1 / 3}
$$

などがあり (9)、特に風浪とうねりが重なってくると、 周期分布の広がりは大きくなり、（3.7）式における 係数も大きな幅を持つ。今回のシミュレーションの 場合を船速の影響がない横波で計算した結果、係数 は1.18となった。また、有義波周期と平均周期 $\bar{T} の$ 関係も同様に大きな幅を持つが、平均的な関係とし ては、

$$
T_{1 / 3} \fallingdotseq 1.18 \bar{T}
$$

が成立すると報告(9) されている。この係数について も同様に今回のシミュレーション結果から計算した ところ係数は 1.20 となり、ほぼ同じ結果となった。 これらを考慮すると図6においてスペクトルピーク 出会い周期が他の周期に比べ長めに示されたのは当 然の結果とも言之る。

図 7 に追い波における 3 種類四つの出会い周期の グラフを示す。同じく縦軸は周期(秒)、横軸は船速 (k’t)である。図によればいずれの場合も10k'tまでは 出会い周期は長くなっている。しかし、その後船速 が上がるにつれスぺクトルピーク出会い周期は長く

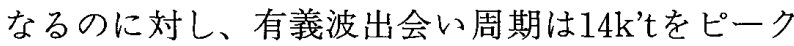

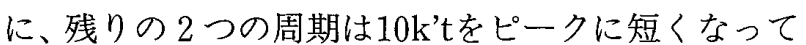

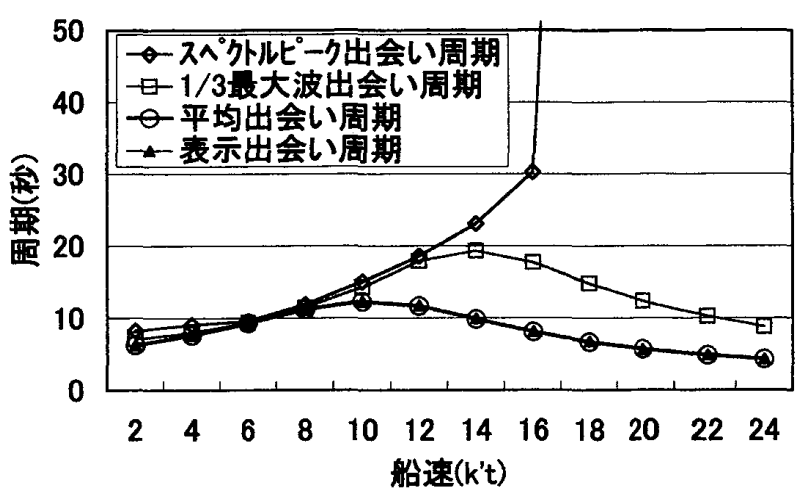

図 7 追い波における出会い周期

いく。このことを一例として図 8 に示すように船速 が24k't追い波のシミュレーション波形 (下段) から 考察すると、全体を通して長周期が存在しているが、 ゼロアップクロス法では細かな変動しか読みとれて いないことがわかる。反対に、スペクトルピーク出 会い周期は、フーリ工変換で解析可能な最も低周波 にピークがあり（上段）、図 7 には示していないが、 スペクトルピーク周期は $24 \mathrm{k}$ 七で最長 1000 秒を越え る周期を示し、その後、船速の増加と共に短くなる。

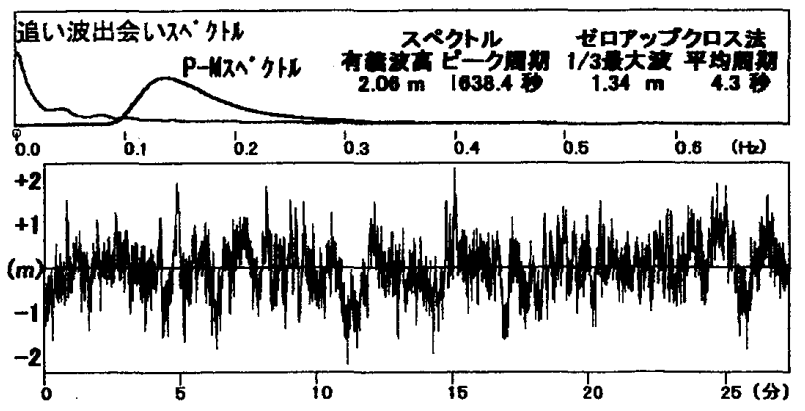

図 8 船速 $24 \mathrm{k}$ 't追い波のスペクトルとシミュレー ション波形

(上段：スペクトル，下段：シミュレーショ ン波形)

図 9 に波向き別表示出会い周期の標準偏差の300 回シミュレーションにおける平均を示す。縦軸は周 期の標準偏差、横軸は船速 $(\mathrm{k}$ 't $)$ である。向波では図 6 に示したように表示出会い周期が短くなるに伴っ て、表示出会い周期の標準偏差も小さくなる傾向が ある。追い波では図 7 に示したように10k'tで周期が 最も長くなるが、出会い周期の標準偏差は12１6 k’t で最も大きくなる。これらの船速でのシミュレー ション波形を調べたところ、出会い波形も $8 \mathrm{k}$ 'tまで は原波浪の波形に似た非常に滑らかな波形であるの に対し、10 k’t以降では細かな波形変動が現れてく る。特に12 16 k’tでは本来の周期であるべき長い周 


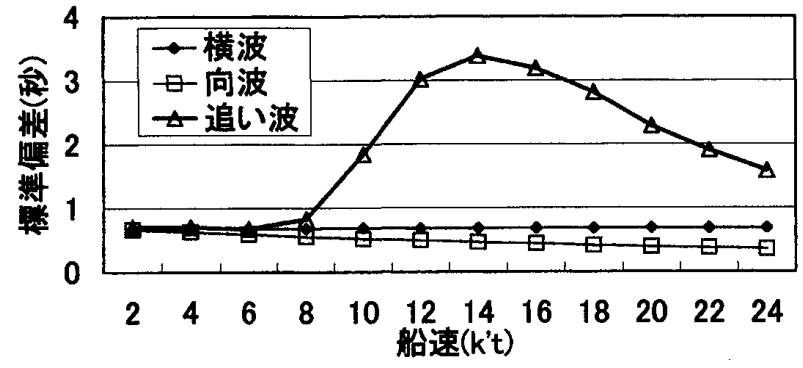

図 9 表示出会い周期の標準偏差

期でゼロアップクロス点を通るものと細かい周期で ゼロアップクロス点を通るものの混在が激しい。そ してスペクトルエネルギーは小さいが、かなりの高 周波の成分を持った波が存在していた。結局、表示 出会い周期といえどもゼロアップクロス法を用いて いるので、様々な周期の影響を受けることになる。 このため出会い周期の標準偏差が大きくなったと思 われる。また、このことは船舶に追い越される波の 成分と船舶を追い越す波の成分が両方とも多く混在 していることを表し、実時間での周期表示を難しく させていると思われる。

\section{4. 考察}

\section{1 波 高}

3 種類それぞれの算出方法や波向きの違いによ ク、波高の值はまちまちであったが、スペクトル換 算波高が最も針路、船速に影響されない安定的な值 を示した。これは航走海面における波浪のスペクト ルエネルギー総和（波形データの分散）は成分波の 周波数に関係なく、振幅だけに依存しているためで あり、当然の結果とも言える。

これに対し、ゼロアップクロス法による有義波高 (1/3最大波高)については、観測時間内における成 分波間の相対出現回数に関係するため、周期の長い 波は出現回数が少なくなり結果としてその成分波高 は有義波高に反映されなくなる。特に船速が卓越波 の波速に近い追い波においては卓越成分波の出現回 数が少なくなり、有義波高は正しく算出されていな いと言える。図10にゼロアップクロス法による $1 / 3$ 最 大波高の300回における標準偏差を示す。図によれ ば、追い波の場合、船速によっては有義波高が大き く変動することがわかる。これは、実船計測におい て追い波では計測波高（有義波高）のばらつきが大 きいと言う報告(4) と一致している。

また、スペクトル換算波高は波向きにかかわらず、 全体を通してゼロアップクロス法による有義波高よ りも波高值が大きかった。このことを横波つまり船

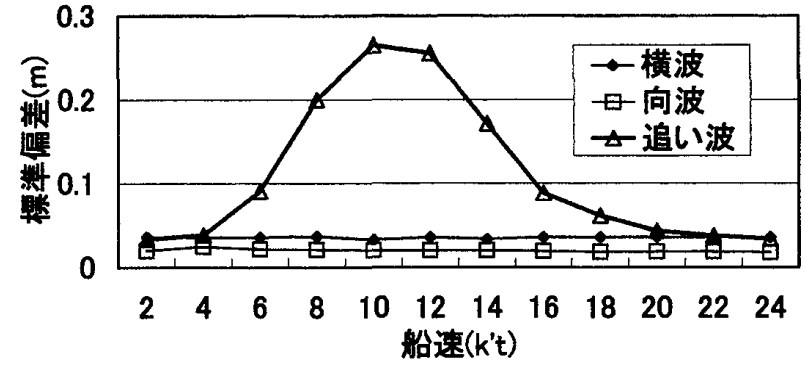

図10 有義波高の標準偏差

速の影響がない場合で考えると、ゼロアップクロス 法による有義波高と比べ約 $4.5 \%$ ほど大きい。の大 きさの関係から (3.1) 式の換算係数を計算すると約 3.82 となる。このことは (3.1) 式において、有義波 高 $H_{s}$ 求める換算係数は実測波形については4.004 ではなく、3.8の方が妥当のようであると言う報 告(10)とほぼ一致している。

表示波高は、向波の時はいずれの場合もほとんど 変化が無かったが、追い波で船速が増してくると僅 かに大きくなる傾向がある。ただし、スペクトル換 算波高やゼロアップクロス法による有義波高のいず れと比べても波高值を小さく示している。このこと は（3.3）式における係数が (3.1) 式をもとに求め られていることから当然の結果と言える。したがっ てゼロアップクロス法による有義波高に合わせるた めには (3.3) 式の表示のための換算係数を10ではな く、1 割程度大きくすべきことを示している。

また、追い波の表示波高の標準偏差も船速が増す と大きくなる。これは、波高計の表示器を見た時に よって、実際の波高とはズレがある場合が考えられ る。このズレを減らすためには、表示波高の標準偏 差の大きさに応じて、(3.4) 式の時定数や平均時間 を変える等の操作をする必要がある。

\section{2 出会い周期}

出会い周期においても 3 種類それぞれの算出方法 や波向きの違いにより、その值はまちまちであった が、向波、追い波とも平均出会い周期と表示出会い 周期はほぼ同じであった。一方、スペクトルピーク 出会い周期において、向波の場合、他の方法による 出会い周期と比べてやや周期を長めに示す傾向が見 られた。このことは第 3 章、第 2 節で述べた通り、 スペクトルのピーク周期と有義波周期と平均周期の 関係で、(3.7) 式と (3.8) 式によるものと思われる。

図11に向波における船速毎のゼロアップクロス法 での周期別平均頻度を示す。これは一連の波形中に ゼロアップクロス法により得られた周期の頻度を表 したもので、それぞれの船速につき 300 回行った平均 


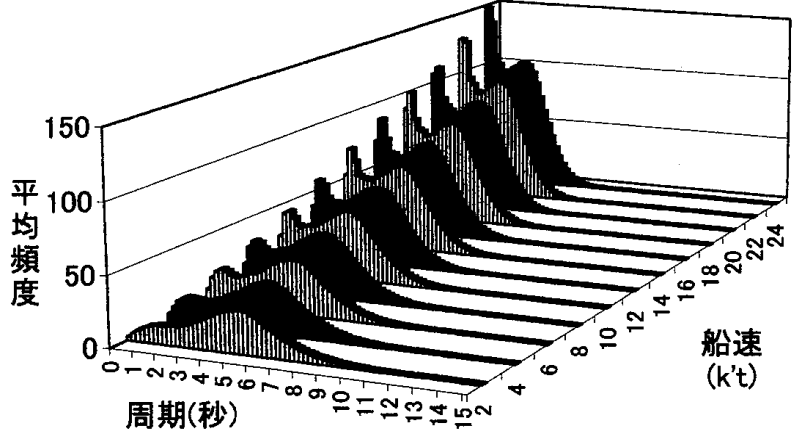

困11 向波におけるゼロアップクロス法での周期別 平均頻度

である。つまり、一連のシミュレーション波形にお いて何秒の周期がどのぐらいの頻度で発生するのか を調べたものである。縦軸は平均頻度、横軸は周期 (秒)、一番手前が船速 $2 \mathrm{k}$ 'tの場合で $2 \mathrm{k} \mathrm{k}^{\prime} \mathrm{t} つ$ つ順に一 番奥が24k’tの場合である。向波であるから、船速が 增すにつれて出会い周期は短くなるのは当然であ る。しかしここで注意すべきは、この図の速度別全 平均がゼロアップクロス法による平均出会い周期と 言うことである。図によれば、船速により頻度は異 なるが、頻度のピークが二力所ある。0秒に近い周 期は細かな雑音成分のような波形が平均水面を切っ て上下しただけで、本来の周期とは言いがたい。つ まり、本来の卓越波の周期は長周期側のピークにあ ク、ゼロアップクロス法による平均出会い周期では それを特定できていない。

さらに、追い波でも同様であり図12は追い波にお ける船速毎のゼロアップクロス法での周期別平均頻 度であるが、図によれば、特に船速が増し細かな波 形が多く存在してくると、頻度のピークは 0 秒付近 の一力所に集まってくる。そのため完全に本来の卓 越波の周期を見つけることはできていない。追い波 中（特に船速が速い場合）において、ゼロアップク 口ス法は有義波高 (1/3最大波) と同じく出会い周期 を算出するのに適していないと言える。また、この ことはゼロアップクロス法を用いている表示出会い 周期にも言えることで、ゼロアップクロス法により 検出された短い周期成分の影響を多く受けて表示出 会い周期も短くなると言える。

ゼロアップクロス法により出会い周期を算出する 場合、 $1 / 3$ 最大波における出会い周期の平均、つまり 有義波出会い周期を採用すると、向波では図 6 で示 した有義波出会い周期は、図11に示した長周期側の ピークの周期に比較的近い值を示す。追い波でも図 7 で示した有義波出会い周期は、罒10に示した長周 期側のピーク周期が確認できる $14 \mathrm{k}$ 't程度までは比

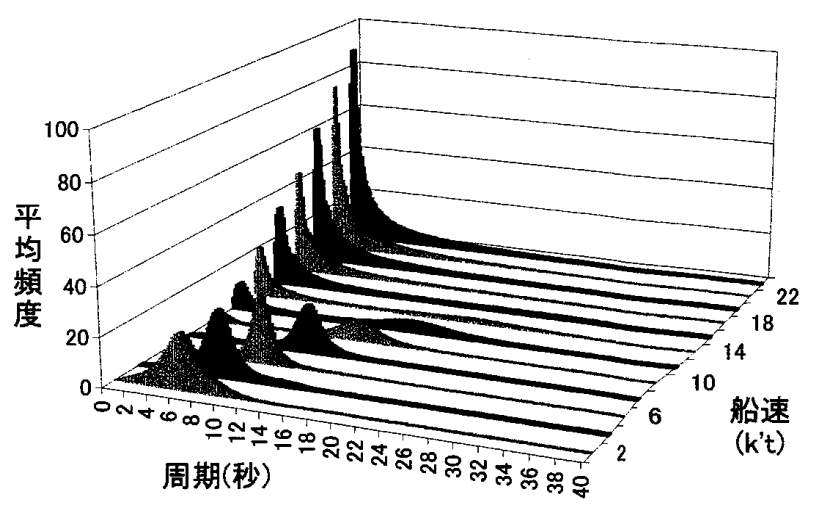

図12追い波におけるゼロアップクロス法での周期 別平均頻度

較的近い值を示す。

\section{5.まとめ}

本研究においては、航走出会い波浪の特性を明ら かにするために計算機内に不規則波を発生させ、そ の不規則波に対して船を走らせた場合に出会うであ ろう出会い波浪を各方向毎に比較した。ただし発生 させた不規則波は周波数スペクトルの成分波を重ね 合わせたいわゆる長波頂波であり、より実際の海面 波に近い短波頂波とは異なっている。この意味では 実際の海面波より方向性を強調したことになるが、 方向別の違いを鮮明にする目的は達せられた。

結果として、航走出会い波浪の代表波高である有 義波高を出会い波形からゼロアップクロス法による 1/3最大波高で定義することは追い波状態で過小評 価となる恐れから不適切である。むしろ、出会い波 浪スペクトルの積分值 (あるいは波形データの分散) から換算される波高をもって代表波高とした方が針 路、船速に影響されず、安定的に原波高（固定点有 義波高）に近い值が得られる。また、波高計に組み 込まれた表示波高回路の指示值は波形によって若干 変動するものの平均的には針路、船速に影響されず 原波高に近い值を示すことが分かった。

出会い周期に関しては有義波周期、スペクトル ピーク周期、表示出会い周期とも針路、船速に応じ て值が変わることは当然あるが、特に追い波状態に おける周期については各々の周期に船速に応じた相 違が表れてくる。出会い周期が原波浪周期（固定点 波浪周期）を表せない以上、いずれの出会い周期も 正しいとは言えず、それぞれの算出方法に応じた当 然の結果を示す。ただし、「追い波状態で船速が波速 と同程度になる出会い周期は無限大に近づくのでは ないか」という直感に近い值を示す周期は、スペク トルピーク周期である。この意味で出会い周期には 
スペクトルピーク周期を採用した方が納得しやす い。しかしながら、将来的には波向きを判別するこ とによる原波浪周期の推定に努力すべきであろう。

\section{参 考 文 献}

（1）桑島進：特集波浪デー夕「目視による波浪の観 測」, TECHNOMARINE (日本造船学会誌), 第831号, pp. 11-19, 平成10年 9 月.

（2）安田明生・金居康文・桑島進：「マイクロ波を 用いた舶用簡易波高計の開発」, 日本航海学会論 文集，第66号，pp. 31-38，昭和57年 2 月.

（3）坂元賢治・小幡紀一：「マイクロ波式波高計の 改良について」, 神戸海洋気象台部内研究発表会 概要, $2 \mathrm{p}$, 平成11年11月。

(4) 矢吹英雄：「マイクロ波式波高計の使用結果に ついて」, 日本航海学会航法研究部会 (AUNAR) 発表概要， $2 p$ ，平成10年12月.

(5) Pierson, W. J. and Moskowiz, L. : A proposed spectral form for fully developed wind seas based on the similarity theory of S. A. Kitaigorodskii, J. Geophys. Res., No.69, pp. 5181-5190, 1964.

(6) Sverdrup, H. U. and Munk, W. H. : Wind sea and swell. Theory of relation for forecasting, U. S. Navy Hydrogr. Office, Washington. No. 601, 44p., 1947.

(7) Longuet-Higgins, M.S.: On the statistical distribution of the height of sea waves, J. M. R., Vol. 11, pp. 245-266, No. 3, 1952.

(8) Yasuda, A., S. Kuwashima and Y. Kanai : A ship borne-type wave height meter for ocean going vessels, using microwave Doppler radar, IEEE. J. of Ocean Engineering, Vol. OE -10. No. 2, pp. 138-143, April 1985.

（9）山口正隆：「重回㷌分析に基づく波浪の統計的 特性の検討」, 第33回海岸工学講演会論文集, pp. 139-143，昭和61年.

（10）合田良實 - 高山知司・岸良安治：「有義波高指 示計の理論およびその実用化について」, 港湾技 研資料, 運輸省港湾技術研究所, No. 238, $12 \mathrm{p}$, June 1976.

\section{質 疑 応 答}

梅田直哉 (大阪大学)： $\omega_{\mathrm{e}}=0$ 付近の波は時系列上で 一定に近くなり、有限時間のrealizationではゼロ アップクロスがなくなります、この点がゼロアッ プクロスで有義波高がずれてくる原因でしょう 加。

桑島 進：質問者の例は特別な一因として考えられ ます。一般的な原因としては成分波の出会い周波 数 $\omega_{\mathrm{e}}$ が 0 に近づく（出会い周期が長くなる）ほど その成分波の出現回数が観測時間内において少な くなり、その成分波高が有義波高算出に反映され なくなることです(本文「考察」参照)。したがっ てゼロアップクロスが無くなる特別な例でなくて も、少なくなるだけで有義波高はずれてきます。 図 8 のスペクトル図に示すようにエネルギー（波 高)の大きい卓越成分波の出会い周波数 $\omega_{\mathrm{e}}$ がゼロ に近くなるほど有義波高の減少度合いが増すこと になります。 